\title{
Sustainable Development and Tourist Satisfaction in Historical Districts: Influencing Factors and Mechanisms
}

Wenting Yu ${ }^{1}$, Jiaming Liu ${ }^{1,2, *}$, Shuying Zhang ${ }^{1,2}$ and Tao Li ${ }^{1,2}$

1 Institute of Geographic Sciences and Natural Resources Research, Key Laboratory of Regional Sustainable Development Modeling, Chinese Academy of Sciences, Beijing 100101, China; yuwenting708@126.com

2 College of Resources and Environment, University of Chinese Academy of Sciences, Beijing 100049, China; zhangshuying231@163.com; nnulitao@163.com

*Correspondence: liujm@igsnrr.ac.cn

\begin{abstract}
How to achieve sustainable development and protection of historical district is a worthwhile research topic. As a vital way to update urban space, tourism development in historical district is an effective solution to redistribute urban functions and increase urban vitality. This paper takes the Insadong in South Korea as a case to carry out the evaluation of tourist satisfaction in historical districts. The research finds that: 1) The tourist satisfaction evaluation of Insadong includes 6 dimensions in total, namely "Embodiment of historical elements", "The blend of tradition and modernity", Industry distribution and type", "Consumer demand", "Street layout and function", "Landscaping". The most satisfying for tourists is "Landscaping", and the most dissatisfying is "Street layout and function". 2) "The blend of tradition and modernity" has the highest weight while "Industry distribution and type" has the lowest one in the analysis of influencing factors on overall satisfaction. 3) The analysis of the common factor weight and the common factor satisfaction shows that "The blend of tradition and modernity" and "Street layout and function" are the parts that need to be improved. "Consumer demand" also has a lot of room for promotion. The research results will benefit to enhance the tourist experiences of historical district and provide theoretical basis and practical experience reference for effective protection and sustainable development of historical district.
\end{abstract}

Keywords: Historical district; Sustainable development; Tourist satisfaction; Insadong, South Korea 


\section{Introduction}

The historical district is essential cultural heritage protection object due to extensive intrinsic values such as historical culture, aesthetic art, material legacies and human emotion. Under the influence of economic value perception, experience economy, location bidding and consumer culture, tourism has become an effective way to stimulate the vitality of historical district, protect and utilize the cultural environment of historical district. However, in the absence of scientific management and regulation mechanisms, historical district are prone to fall into the opposite poles of rigid protection or excessive commercialization in terms of original culture [1-3]. How to effectively conserve historical district in contemporary urban construction, and guarantee sustainable development through deep excavation of urban life forms and spatial characteristics, has become a topic to be discussed.

Although many scholars have carried out a lot of researches on the sustainable development of historical district, these studies are mostly focused on historical and cultural protection or commercial consumption. Few combined two aspects into a comprehensive analysis. In fact, the sustainable development of historical district needs to consider a variety of factors. As a precious cultural heritage, the historical district contains rich urban memories. It not only witnesses urban evolution and manifests traditional culture, but also plays a basic role in tourism decision-making of tourists. Hence, there exists practical significance on the protection of historical district.

However, with the era of consumption, the consumption concepts and consumer demands of residents have undergone tremendous changes. In order to meet the needs of modern consumption, it is necessary to regenerate the historical district all roundly [4,5]. Undoubtedly, the subjective elements like tourists' demands, behaviors and values, and the objective elements such as historical district culture, architecture and landscape, should be regarded as equal important development targets.

The recession problems faced by historical districts are complex: functional agglomeration but low land use, dense population but inadequate public facilities, dense traditional buildings but insufficient protection [6]. At the same time, the problems such as aging and obsolescence of infrastructure, traffic congestion, and poor living environment also pose severe threats to efficient regeneration of old towns $[7,8]$. The study of historical district is not only about the assessment of its current status and values but, more fundamentally, also about how to effectively protect and sustainably develop. To embrace the above-mentioned rationale, this paper sorts out the process of protection and renewal of Korean historical districts, and takes Insadong as an example to construct 
a support impact evaluation system for the sustainable development model of historical district. In particular, the perspective of tourists is addressed through integrating urban culture with consumer demand.

\section{Literature Review}

\subsection{Protection and sustainable development of historical districts}

Historical districts extend the concepts of "historical center" or "building complex", including broader urban context and geographical environment [9]. Correspondingly, the value of historical districts should be explored with dynamic, active, sustainable views in a wider urban background.

By linking the daily life of the citizens with the history and culture, the values of historical districts are reflected in the inheritance of the spirit and culture of the citizens. Historical districts are largely inseparable from regional influences and are rooted in the local historical context. Just like urban history museum, they reflect the regional characteristics of a region under the influence of social culture and economy. Historical districts with developmental value are generally well-preserved and well-structured, which have excellent images, perfect businesses, and significant historical and cultural statuses. Endowed with special responsibility of transforming the images of old cities, historical districts play a vital position in repairing buildings, replacing spatial functions, promoting public environment and perfecting supporting facilities. They are inestimable tangible as well as intangible resources for cities [10-12].

Under the background of urbanization from incremental expansion to stock exploration, the historical districts located in the city center are the key areas for the improvement of urbanization quality, and are generally the most abundant areas of urban historical and cultural heritages. The rational development of urban historical districts and the coordinated management of functions, industries, facilities and spaces are important topics for protection and renewal $[13,14]$.

\subsection{Tourism development and protection and sustainable use of historical districts}

Tourism is a regeneration method commonly used in historical districts. Tourism development promotes the continuous adjustments of the relationships and behaviors between tourists and residents, thus achieving the sustainable conditions of the district[15]. The historical district environment is intimately bound up with tourism activities, admittedly, but the protection and development of historical districts should be based upon tourism development mode [16,17].

Historical districts are not only a tourism product, but also a living space for local residents. 
Tourism intervention and historical development need to be interactive and balanced. In addition to the protection of historical building facilities, tourism development also coordinates the relationship with local communities, pays attention to the experience of tourists, and avoids simplistic contents and forms [18-20]. In order to gain the approval of various stakeholders, the balance of "Protection" and "Development", which are the two major focuses of tourism development in historical districts, should be addressed [21-23].

\subsection{Protection and renewal of historical districts in Korea}

After the war, South Korea began to enter the stage of economic recovery in the 1960s. With the expansion and development of the city, old areas and traditional areas including historical districts were greatly affected. The "Urban Planning Law" issued in 1962 has already begun to involve the content of urban regeneration. However, in the national land planning, the first comprehensive land development plan (1972-1981) still stayed at the stage of large-scale development of industrial land and vigorously developed urban construction. After realizing this problem, the Korean government began to adjust policies. In third comprehensive land development plan (1992-2001), the tasks were shift to enlarge land intensive use, restrict excessive expansion of the metropolitan area, encourage multi-nuclear development and create regional characteristics [24]. Through a period of experiences, the legalization of urban regeneration has been fully carried out since 1990s, providing policy support and guidance function for urban regeneration [25].

During the period of the 1988 Seoul Olympics, South Korea began to promote the urban beautification movement. Foreign tourists showed great interests in Korean culture, especially for Hanok (Korean traditional house) and Korean food. However, there was no relevant development about traditional tourism types at that time. The preservation of Hanok and the regeneration of historical and cultural districts began to increase until to the 1985 [26]. On January 23, 2007, the Ministry of Land, Infrastructure and Oceans established the Urban Recycling Group, which was committed to improving the urban recession from various aspects such as society, economy, and practice. It is based on actual protection and renewal, cooperating with the Ministry of Culture and Tourism and carrying out historical and cultural tourism (Figure 1). 


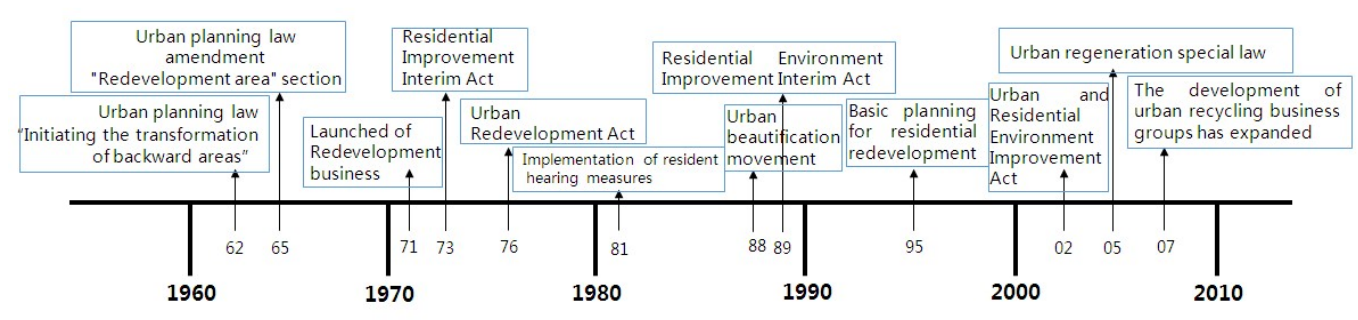

Figure 1. Change process of Urban Regeneration Policy in Korea

South Korea has developed from a resource-poor peninsula country to a tourism destination with high standard services. It is because South Korea attaches great importance to tourism resources, especially the protection and renewal of cultural tourism resources. It is worth mentioning that Korea's representative historical and cultural districts have become well-known tourist attractions after regeneration. The Ministry of Culture and Tourism established by the Korean government attaches equal importance to culture and tourism, which are mutually promoted and developed. Cultural and historical landscapes serve tourists and in turn exports Korean culture to tourists [27].

\section{Materials and Methods}

\subsection{Case selection}

Located in Jongno-gu, Seoul, South Korea, Insadong is one of the earliest historical districts in Seoul(Figure 2). It gathers historical and cultural forms such as Hanok, ancient arts and galleries, and attracts a large number of tourists every year. The Insadong district experienced a period of extreme decline during the Japanese occupation period [28]. After the Korean economy recovered in the 1960s, Insadong began to spontaneously carry out conservation and regeneration activities. In the 1980s, the Korean government realized the importance of historical and cultural districts, and supported the historical restoration and tourism development of Insadong from policies and regulations, which makes Insadong become the most influential historical district in Korea. The traditional Hanoks in Insadong is an important part of Seoul's central city and is the basis for the feature of city scape. The development of Insadong reflects the emphasis of Korea's policy towards historic districts. Its architectural structures and artistic symbols are also important historical and cultural heritages [29-31].

This study combines on-the-spot investigations with theoretical researches. The data, including commercial structures, tourists' satisfactions, local and tourists' interviews, were mainly 
collected in Insadong from May to July 2017, which are the basis for following analyses about policies implementation and marketing promotion.

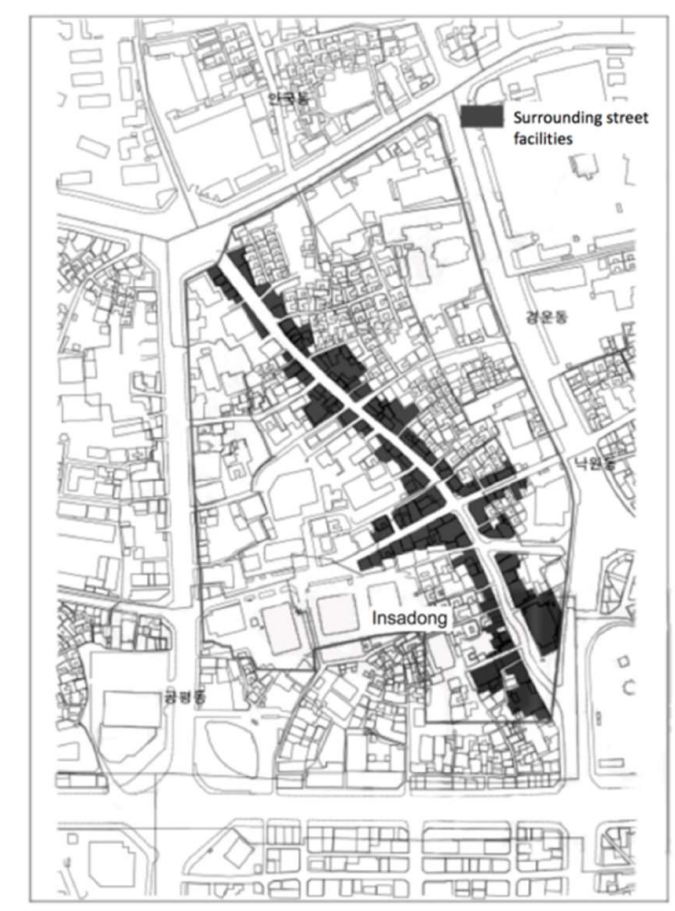

Figure 2. The location of Insadong

\subsection{Questionnaire design and data analysis}

Evaluation factors are selected from the perspectives of protective development, sustainable development and usage perception in historical districts, in order to truthfully show current situation and feasibly summarize experience. 550 questionnaires were achieved during the questionnaire survey. After eliminating empties and outliers, 507 valid questionnaires were taken as data source (recovery rate $92.18 \%$ ). According to Likert scale, the indicators in questionnaire were measured by five levels (very poor, poor, general, good, very good, respectively assigned 1, 2, $3,4,5)$. Respondents were asked to express their subjective judgments and satisfactions about Insadong .

SPSS was used for descriptive statistical analyses, obtaining general statistical indicators such as sample mean, variance, and frequency distribution. Since the questionnaire contains 33 indicators, the factor analysis method was firstly performed to obtain the comprehensive evaluation index of tourists on this historical district. Then taking the comprehensive evaluation index as independent variables and the overall satisfaction as dependent variable, the multiple linear regression analysis was carried out to explore the influence weights of different factors on the 
overall satisfaction. The importance-performance analysis grid was drawn and regarded as basis of quantitative evaluation [32-36]. Invisibly, the research results are of significance to scientific planning and sustainable development of historical districts.

According to the survey results of questionnaires, the sample has a balanced gender distribution, the percentage of female respondents (54\%), is relatively higher than male (46\%).The two largest age groups are the middle aged (31-55 years old) and the young (under the age of 30), accounting for $32 \%$ and $22 \%$ respectively. In terms of transportation means, most people chose public transport (198 people), accounting for $39 \%$.

\section{Results}

4.1. Factor Analysis

Table 1. Test of KMO and Bartlett

\begin{tabular}{lc}
\hline Test result & Value \\
\hline Kaiser-Meyer-Olkin measurement sampling suitability & 0.866 \\
Bartletts pherical test & 7654.5 \\
Degree of freedom (df) & 518 \\
Significance & 0.000 \\
\hline
\end{tabular}

As can be seen from Table 1, the value of Bartlett spherical test is 7654.5, and the corresponding probability $\mathrm{p}$ is close to zero. If the significance level $\alpha$ is 0.05 , the null hypothesis should be rejected due to the low p-value (less than $\alpha$ ), and the correlation coefficient matrix and the identity matrix are statistically significant. According to Kaiser's opinion, the KMO value (0.866) indicates original indicators are suitable for factor analysis and further research. In this study, the factor analysis method was used to extract the common factors. The number of common factors was gained through analyzing variances of each vindicator. First of all, the common factors were rotated by the orthogonal maximization of indicators, and the coordinates transformation was used to ensure the largest variances loaded by common factors. The rotated factor load matrix has the following two characteristics: 1) Any indicator has a high contribution rate only on one common factor, and the load factor on other factors approaches 0;2) Any common factor has a high load factor on only a few problems, while the load factor on other indicators approaches zero. This factor rotation makes the factor load of each problem polarized, which is easier to explain the practical significance of each common factor. 
Table 2. The results of factor variance

\begin{tabular}{cccc}
\hline Factor & Eigen values & Variation variance \% & $\begin{array}{c}\text { Cumulative variation } \\
\text { variance \% }\end{array}$ \\
\hline 1 & 6.327 & 19.104 & 15.877 \\
2 & 5.031 & 13.393 & 29.866 \\
3 & 3.679 & 11.412 & 41.583 \\
4 & 2.833 & 9.292 & 50.875 \\
5 & 2.482 & 7.617 & 58.492 \\
6 & 1.166 & 4.364 & 62.856 \\
\hline
\end{tabular}

Table 2 shows that there are totally six common factors with $62.856 \%$ of cumulative variance contribution rate, which means that the first six common factors explain $62.856 \%$ of the variation of all indicators. Hence, the six factors can reflect most of the information of original indicators.

After rotating the load matrix, common factor 1 has highest loading coefficient on Q1, Q2, Q3, Q4, Q5, Q8, Q9, common factor 2 is highest on Q28, Q29, Q30, Q31, Q32, Q33; common factor 3 is highest on Q22, Q23, Q24, Q25, Q26; common factor 4 is highest on Q17, Q18, Q19, Q20, Q21; common factor 5 is highest on Q6, Q7, Q10, Q11, Q12; and common factor 6 is highest on Q13, Q14, Q15, Q16, Q27. The results of classified evaluation factors can be seen from Table 3 .

Table 3. The significance of factors and evaluation factors

\begin{tabular}{|c|c|c|c|c|c|c|}
\hline $\begin{array}{c}\text { Common } \\
\text { factor }\end{array}$ & $\begin{array}{l}\text { Evaluation } \\
\text { indicator }\end{array}$ & Factor load & Mean & $\begin{array}{l}\text { Mean } \\
\text { common } \\
\text { factor }\end{array}$ & Eigenvalues & $\begin{array}{c}\text { Variance } \\
\text { contribution } \\
\text { rate } \%\end{array}$ \\
\hline Factor1Embo & $\begin{array}{l}\text { Historical street } \\
\text { form is well } \\
\text { preserved }\end{array}$ & .843 & 4.24 & \multirow{3}{*}{3.999} & \multirow{3}{*}{6.321} & \multirow{3}{*}{14.967} \\
\hline \multirow[t]{2}{*}{ elements } & $\begin{array}{l}\text { Historical } \\
\text { building facilities } \\
\text { are well preserved }\end{array}$ & .947 & 4.09 & & & \\
\hline & $\begin{array}{l}\text { Intangible culture } \\
\text { such as folk }\end{array}$ & .832 & 4.03 & & & \\
\hline
\end{tabular}




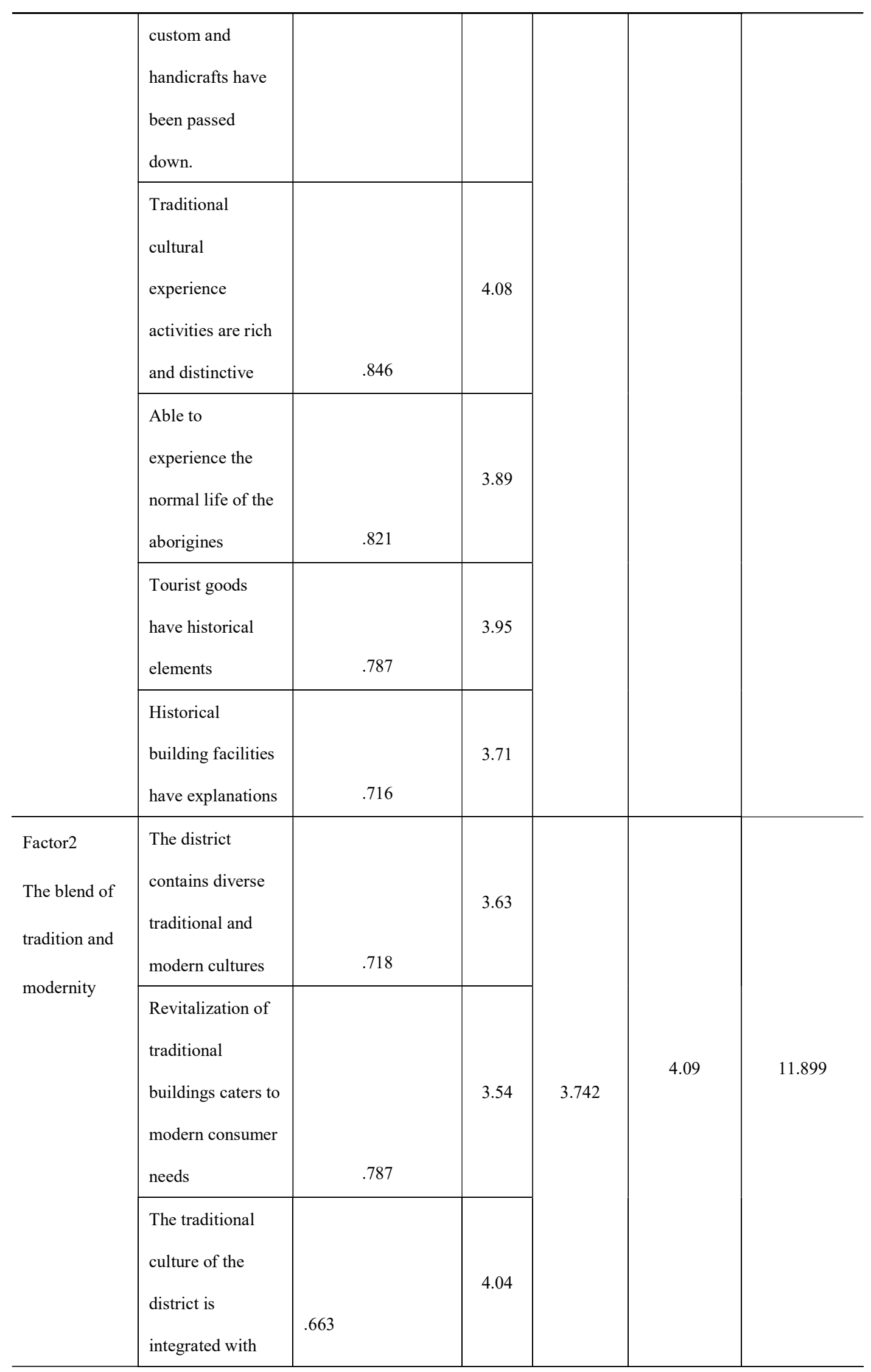




\begin{tabular}{|c|c|c|c|c|c|c|}
\hline & $\begin{array}{l}\text { modern culture } \\
\text { through creative } \\
\text { means. }\end{array}$ & & & & & \\
\hline & $\begin{array}{l}\text { Reproduce the } \\
\text { historical features } \\
\text { of the district by } \\
\text { modern technical } \\
\text { means }\end{array}$ & .776 & 3.54 & & & \\
\hline & $\begin{array}{l}\text { Old brands and } \\
\text { traditional } \\
\text { handicrafts are } \\
\text { passed down and } \\
\text { carried forward } \\
\text { through modern } \\
\text { culture. }\end{array}$ & 更 & 3.78 & & & \\
\hline & $\begin{array}{l}\text { The district can } \\
\text { represent the } \\
\text { traditional and } \\
\text { modern image of } \\
\text { Seoul }\end{array}$ & .701 & 3.92 & & & \\
\hline $\begin{array}{l}\text { Factor } 3 \\
\text { Industry } \\
\text { distribution }\end{array}$ & $\begin{array}{l}\text { The format of the } \\
\text { district has } \\
\text { distinctive } \\
\text { features }\end{array}$ & .760 & 3.99 & \multirow{3}{*}{3.848} & \multirow{3}{*}{3.769} & \multirow{3}{*}{10.016} \\
\hline \multirow{2}{*}{ and type } & $\begin{array}{l}\text { Diversified store } \\
\text { types meet } \\
\text { different needs of } \\
\text { visitors }\end{array}$ & .812 & 4.12 & & & \\
\hline & $\begin{array}{l}\text { The scale of the } \\
\text { store is diversified } \\
\text { and the size is } \\
\text { reasonable }\end{array}$ & .766 & 3.75 & & & \\
\hline
\end{tabular}




\begin{tabular}{|c|c|c|c|c|c|c|}
\hline & $\begin{array}{l}\text { The distribution } \\
\text { of shops and } \\
\text { residential houses } \\
\text { is reasonable }\end{array}$ & .681 & 3.47 & & & \\
\hline & $\begin{array}{l}\text { Family-run shops } \\
\text { with local } \\
\text { characteristics are } \\
\text { located in the } \\
\text { district }\end{array}$ & .863 & 3.91 & & & \\
\hline \multirow[t]{5}{*}{$\begin{array}{l}\text { Consumer } \\
\text { demand }\end{array}$} & $\begin{array}{l}\text { The format can } \\
\text { meet the } \\
\text { experience needs } \\
\text { of tourists }\end{array}$ & . & 3.79 & \multirow{5}{*}{3.8} & \multirow{5}{*}{3.033} & \multirow{5}{*}{9.832} \\
\hline & $\begin{array}{l}\text { The district can } \\
\text { provide spaces for } \\
\text { leisure and dining } \\
\text { such as dining and } \\
\text { coffee }\end{array}$ & .784 & 3.88 & & & \\
\hline & $\begin{array}{l}\text { Visitors can feel } \\
\text { the cultural and } \\
\text { artistic } \\
\text { atmosphere }\end{array}$ & .871 & 3.86 & & & \\
\hline & $\begin{array}{l}\text { Visitors can feel } \\
\text { the romantic, } \\
\text { refined } \\
\text { consumption } \\
\text { atmosphere }\end{array}$ & .839 & 3.83 & & & \\
\hline & $\begin{array}{l}\text { The consumer } \\
\text { environment can } \\
\text { help visitors } \\
\text { unwind and relax }\end{array}$ & .667 & 3.64 & & & \\
\hline Factor 5 & Environment and & .880 & 3.86 & 3.732 & 2.544 & 8.741 \\
\hline
\end{tabular}




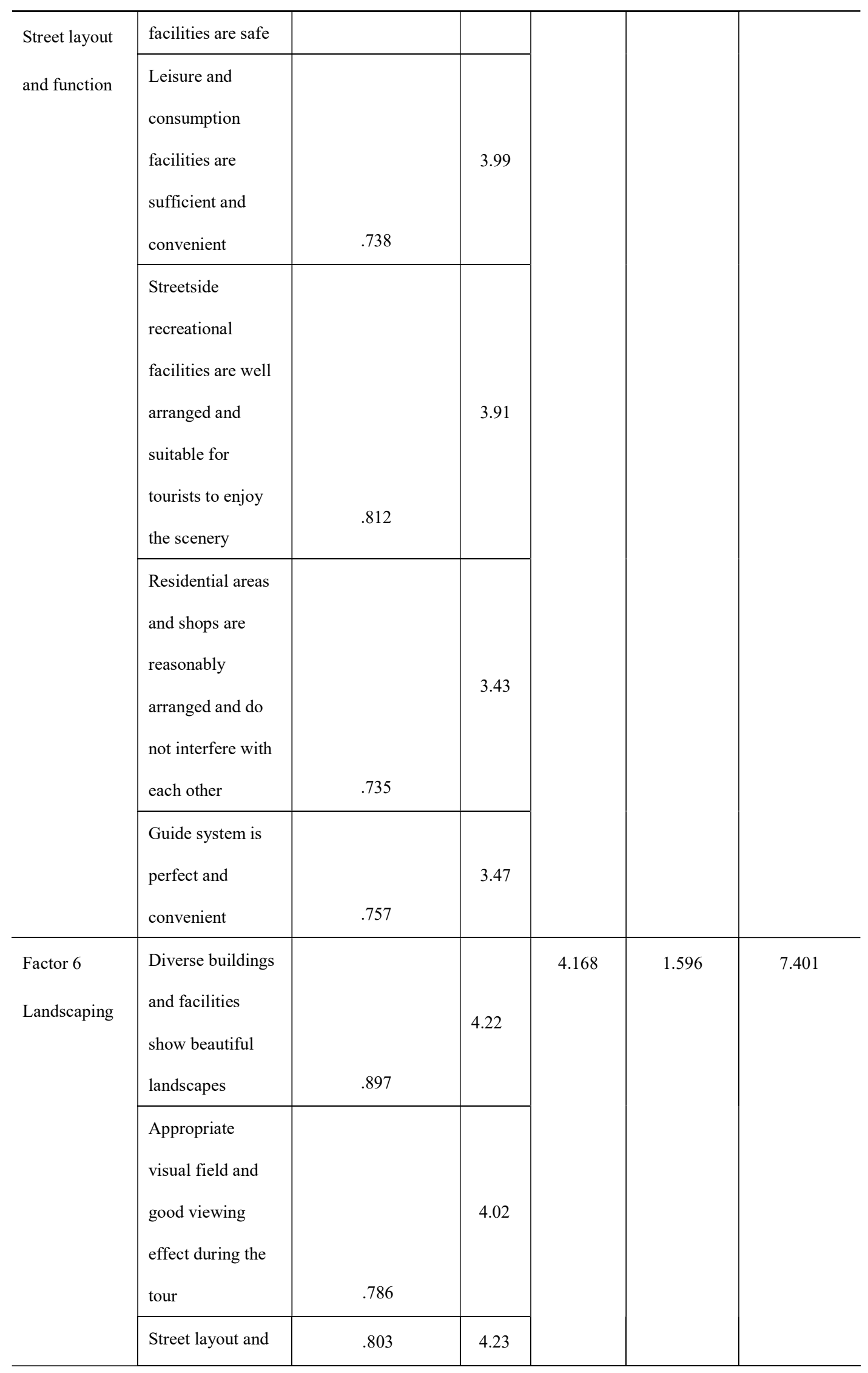




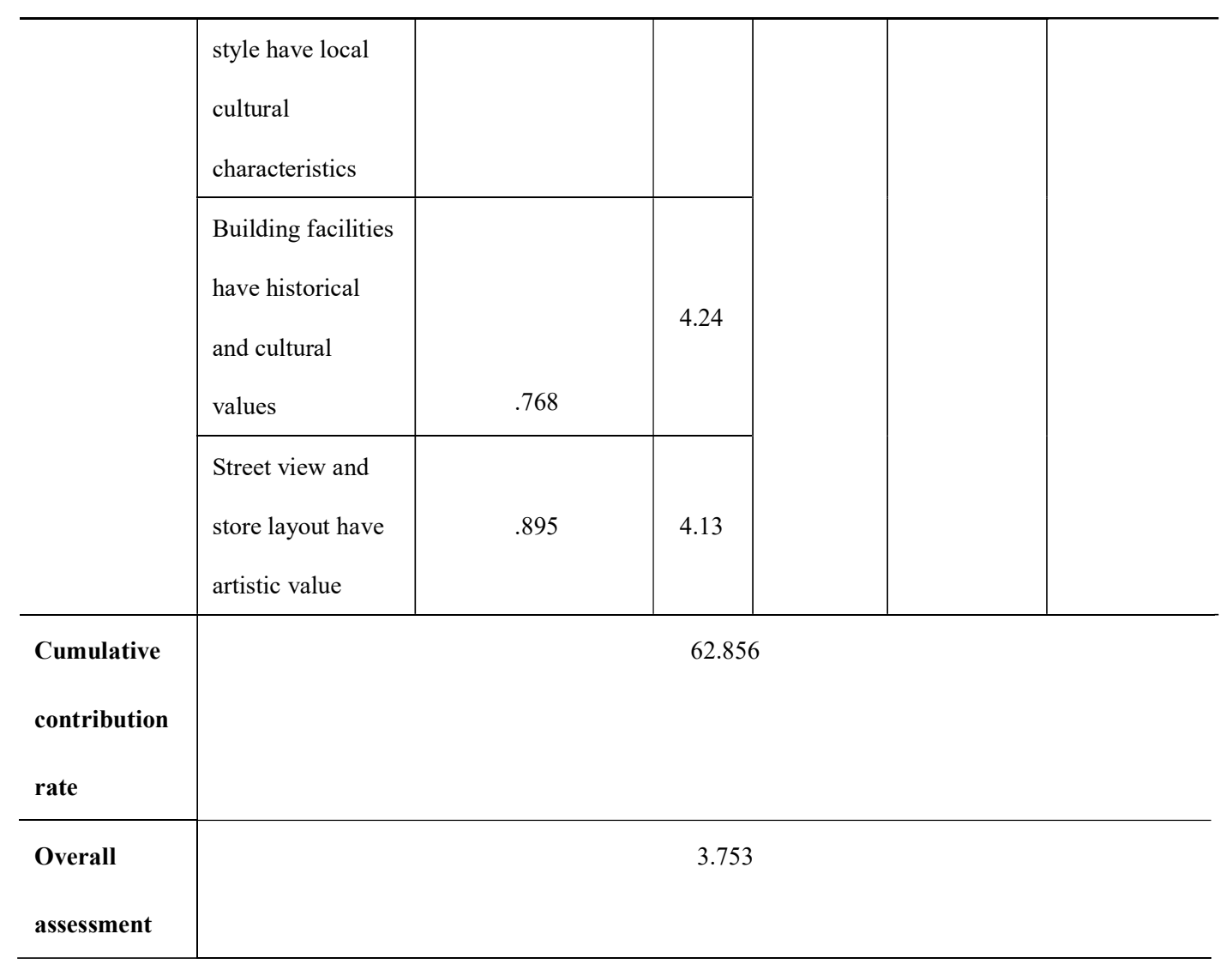

\subsection{Analysis of the influencing factors of sustainable development of historical districts based on tourists' perspective}

\subsubsection{Embodiment of historical elements}

The mean value of "Embodiment of historical elements" is relatively high, ranking second in the list of common factors with a score of 3.99.Visitors believe that "Historical street form is well preserved" (4.24), "Historical building facilities are well preserved” (4.09), "Intangible culture such as folk custom and handicrafts have been passed down" (4.03), and "Traditional cultural experience activities are rich, and distinctive" (4.08). There are many houses of the Korean aristocrats on the district. And there are many famous places and celebrities' former residences hidden in corners.

Between 1960 and 1970, shops in the Insadong operated antiques and ancient paintings gradually increased. In the 1970s, the earliest commercial galleries in Korea were established in the region. Over the next few decades, the region has gathered many galleries to become a collection of modern art and Korean traditional culture. In the collection of traditional culture, Insadong uses this industrial orientation related to traditional art and culture to create a unique place for visitors to understand (Figure 3). 


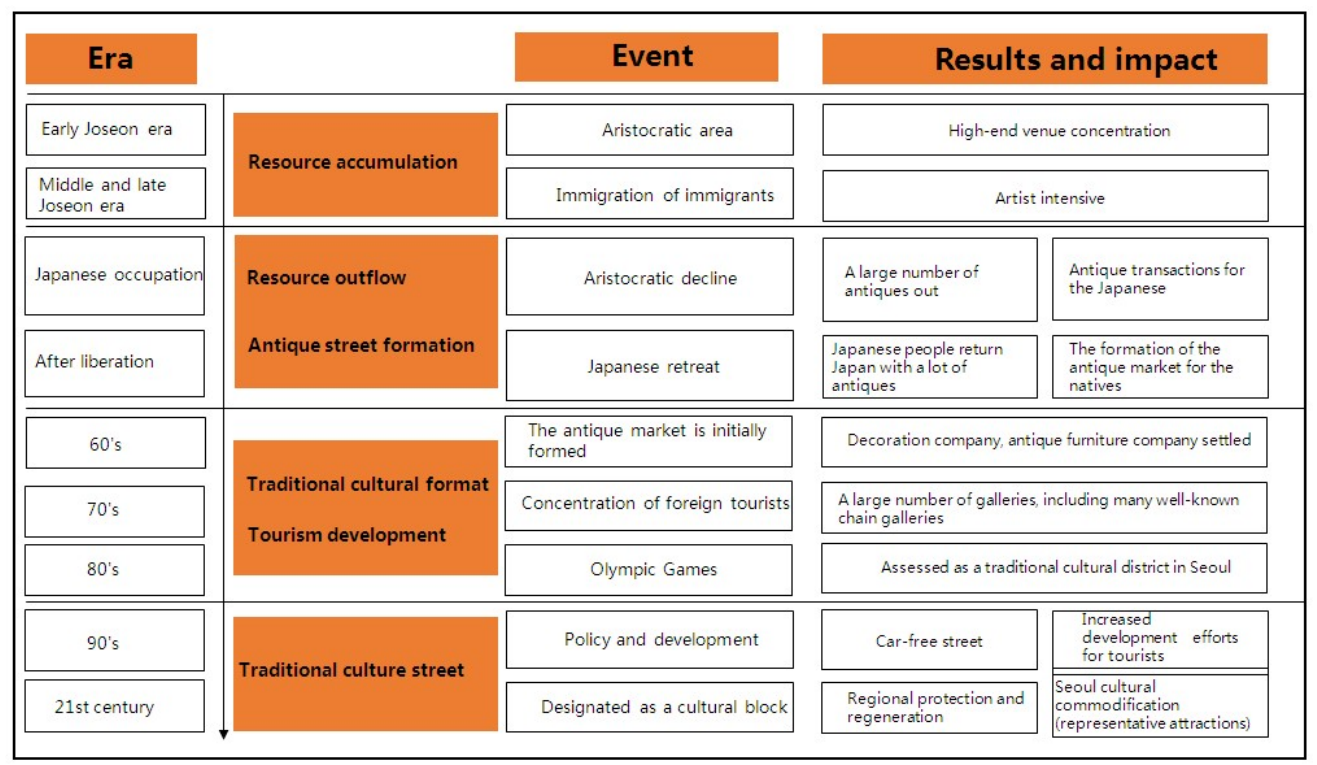

Figure 3. Change process of Insadong district

The original street pattern expresses the historical authenticity through the spatial arrangement of district texture, making visitors feel the depth of history and the tension of time and space. There exist various sizes of traditional streets and Hanoks in the Insadong. It is these historical traces in urban center that distinguish Seoul from other cities in the image and style. Ancient buildings are the preferred places for tourists to take pictures, which increase the interest and commemoration during the tour, indirectly enhances the sense of history and authenticity of historical districts, thereby increasing the satisfaction and support of tourists.

History and culture are the city's first memories with obvious regional characteristics and unique artistic styles. As the most essential information communication in historical districts, they truly reflect the local lifestyles and customs. Therefore, it is common for tourists to sing high price of the tourism development model of enhancing the original atmosphere of historical districts.

According to field researches, the successful convey effect of traditional culture is reflected in the fact that folk museums, traditional galleries and other facilities preserve the folklore and arts, and satisfy tourists' pursuit of cultural authenticity. Moreover, many restaurants provide free folk art performances during mealtime, High-level clubs, especially, have strong cultural experience function, which naturally integrates the intangible culture into traveling. Insadong has always made every effort to preserve the local historical features by retaining the traditional styles of Hanok, using brick roofs in new buildings, adopting nostalgic interior design and other architectural elements, and choosing old-fashioned street elements such as street lights, ground paving and sightseeing guides, to create a traditional district in modern Seoul where visitors can learn about the ancient styles of Korea. 
In the survey, the scores of "Able to experience the normal life of the aborigines" (3.89), "Tourist goods have historical elements" (3.95), and "Historical building facilities have explanations" (3.71) are relatively low. In the past 20 years, the dramatic growth in the number of tourists, foreign tourists in particular, has greatly boosted the sales of local specialty products. However, an increasing number of unoriginal and cheap souvenirs have destroyed the image of this district. These phenomena just confirm the trend of tourism consumption in today's society. Most of the products purchased by tourists are cheap crafts of less than 20,000 won. Unlike the expensive and luxurious products in Insadong in the past, today's tourists are more eager to buy cheap and interesting souvenirs. Therefore, the Insadong should focus on the development of traditional cultural products and traditional foods, and attract overseas tourists through cultural characteristics. At the same time, the detailed interpretation of historical buildings should be supplemented to help visitors to further understand the history of the development of historical districts.

\subsubsection{The blend of tradition and modernity}

The three highest scores in common factor of "The blend of tradition and modernity" (3.742) are "The traditional culture of the district is integrated with modern culture through creative means" (4.04) and "The district can represent the traditional and modern image of Seoul" (3.92), which indicates that the differentiation strategy of cultural and creative industries based on traditional culture and modern demand characteristics is an excellent way to avoid "convergence" and "same images of thousand cities". The "city card" effect is generated by creating an "imprint" exclusive to Seoul. In the process of tourism development in historical districts, by harmonizing and integrating modern cultures of different countries and regions, the symbiosis between traditional and modern cultures will increase the sense of difference and freshness of tourists, and upgrade the sense of life and reduce commercial atmosphere. In particular, the integration of creative culture in the district is based on a new lifestyle experience to create unique highlights that attract visitors. Insadong has profound artistic heritages. It has achieved a good integration through creative industries and tourism and absorbed fresh blood such as modern arts and urban fashion vocabularies, making the district become a gathering place for various artistic elements. The symbiotic development model has been recognized by tourists.

\subsubsection{Industry distribution and type}

Social and economic governance is the focus of the protective development of the district. With the changes of the times, Insadong has encountered many contradictions that are difficult to 
coordinate, such as the increasingly high land prices, the influx of low-end goods and small traders, and the proliferation of global chain stores, such as McDonald's and Starbucks. With the modernization of the city, the traditional business format of the historical district has undergone varying degrees of changes. In the transformation, a business model that adapts to the modern society was adopted, which can ease the contradiction of the district and promote the sustainable development of the district.

The "Industry distribution and type" of Insadong District scores 3.848, including three high-scored indicators, namely "Diversified store types meet different needs of visitors" (4.12), "The format of the district has distinctive features" (3.99), and "Family-run shops with local characteristics are located in the district (3.91). At the beginning of the government's transformation of Insadong, due to the regulation of business format, the retained businesses have convergence to a certain extent. For instance, there are multitude similar teahouses in the streets. A growing number of souvenir shops deteriorate the art level of the district, and some well-known galleries chose to move out. Furthermore, local residents are beset by the surge of arriving tourists. In response to these problems, the government has effectively launched a series of measures. First of all, "Traditional famous stores" that have been in Insadong for more than 20 years, and operate excellent cultural goods are selected and provided necessary fundings. If these stores enjoy the fames but change their business contents or have quality problems that are repeatedly pointed out by the residents' committee and have not been effectively corrected, they will be disqualified. Family-run shops, especially those located in the alleys, are important places for tourists to experience the historical districts in depth, which will affect the staying time and gathering space of tourists, having a great impact on the tourists' perception and support for tourist development patterns in tourist districts.

The government mainly supports and retains shops with local traditional characteristics developed by individual small owners, rather than large commercial places or chain stores, in the form of tax relief and financing. Small-scale buildings and specialty shops have become a feature of the Insadong, which avoids being too similar to the business model in other areas and increases the employment rate of local residents. In order to preserve the traditional features, except for several essential scenic spots and cultural relics, other areas are classified as relatively restricted areas where street vendors peddle their goods along the sidewalk within the specified time. To a certain extent, it guarantees the order of the street, and provides conditions for tourists to experience deep and slow tourism as well. Thereby, it becomes a popular way for traveling. 


\subsubsection{Consumer demand}

In the "Consumer demand" (3.8), "The district can provide spaces for leisure and dining such as dining and coffee" (3.88), "Visitors can feel the cultural and artistic atmosphere" (3.86), "Visitors can feel the romantic, refined consumption atmosphere" (3.83) scored high. On the contrary, "The format can meet the experience needs of tourists" (3.79), "The consumer environment can help visitors unwind and relax" (3.64) need to be strengthened.

Compared to the popular tourist areas and souvenirs that are suitable for short stays and consumption, Insadong addresses leisure and experience, so there are many bars, cafes, homestays, galleries, restaurants and creative shops. Insadong can reflect the connotation of daily life aesthetics, return culture and art to district life, and express elegant culture and art in an easy-to-understand form, so that cultural consumer goods can be integrated into daily life consumption. The cultural and artistic atmosphere enhances cultural experience of tourists. Therefore, catering to the "life-oriented" consumer demand has become an important factor in the artistic development of historical districts. Insadong has become a portrayal of exquisite, warm and petty-bourgeois life, satisfying consumer psychology of urban middle-class people who have a profound impact on support.

\subsubsection{Street layout and function}

"Street layout and function" (3.732) has general score, but "Leisure and consumption facilities are sufficient and convenient" (3.99), "Streetside recreational facilities are well arranged and suitable for tourists to enjoy the scenery" (3.91), "Environment and facilities are safe" "(3.86) are supported by respondents. Serving as important function carriers of historical districts, the leisure consumption facilities and recreation facilities in Insadong meet the needs of tourists for consumption, leisure and viewing, and express the development concept of "leisure" and "humanization", gained high support from tourists.

The scores of "Residential areas and shops are reasonably arranged and do not interfere with each other" (3.43), "Guide system is perfect and convenient" (3.47) are relatively low. The Hanoks in Insadong are served as not only scenic spots for visitors, but also living houses for local residents. The museums and studios in the streets are set up in the Hanoks with local characteristics, but due to the deep tour of tourists, there has a big contradiction among local residents, merchants and tourists.

Excessive tourists and lack of effective management create a large amount of domestic 
garbage, damage cultural relics, and challenge the carrying capacity of tourism. The active line of tourism, commerce and residential areas in many historical districts cannot coordinate with each other, affecting the privacy of the living environment. The conflicts between tourists and residents' needs will lead to the loss of attraction and affinity, which will seriously affect the landscape of the district. Generally, historical districts are located in the center of the city. It is difficult to set up parking lots, park vehicles. The congested traffic isolates road system from original street texture. And there are too many foreign merchants, causing traffic chaos and inconvenient daily life. It is difficult for tourists to arrive or stay. Redundant commercial facilities, crowded living space of local residents, and excessive decoration of commercial facilities cause the destruction of the street landscape image.

In response to these problems, visitors can be guided by planning a number of fixed tour routes and developing a comprehensive guide system. And by changing the opening directions of the courtyards or the traffic lines to avoid the crowded streets and ensure the privacy of the living environment. On one hand, it is necessary to reduce the blind search of tourists for scenic spots; on the other hand, reduce disturbance to daily life of locals to a certain extent by controlling the effective separation of the tourist route and the living space.

The format of the Insadong district can be adjusted to be more experiential and characteristic, such as the textile and embroidery experience store whose images are not unobtrusive, and they enable visitors to fully understand the profoundness of silk and embroidery. While protecting the cultural spirit of the district, cultural activities and tourism image of the historical district should be promoted.

\subsubsection{Landscaping}

The overall score of "Landscaping" (4.168) and the scores of all indicators are relatively high, indicating that Insadong is very successful in the creation of distinctive imagery. The image of the district space has more extensive and profound content and meaning than the district itself. Visitors realize the unique style and artistic atmosphere of Insadong, which positively influences the support of tourists. Since Insadong is located in the center of Seoul, there is no large green space in the original streets. But many shop owners spontaneously planted plants around the storefronts, some shops even have roof gardens, or use vertical greening to increase green areas. While beautifying the store environment, it has created a good street image and played a positive role in the healthy development of the tourism industry. Tourists are satisfied because it embodies the living environment where people and historical districts are organically integrated and interacted, and 
forms a historical district with diversified landscapes and good historical information preservation.

In the development process, Insadong strives to maintain the original style of the streets, and has added a number of unique shops to make the space full of design and fun. The local government vigorously promotes the characteristics of Hanok in the district and advocates in-depth tourism.

While retaining the tradition, through the modern interpretation, the improved Hanok is more attractive and practical, and can attract tourists to visit.

\subsection{Analysis of the influencing factors on overall satisfaction}

In order to measure the relationship between questionnaire indicators and overall satisfaction, six common factors extracted by factor analysis are used as independent variables, and the overall satisfaction is used as the dependent variable for multiple regression analysis. The test results of the linear model are as follows:

Table 4. Test results of model

\begin{tabular}{cccccc}
\hline $\begin{array}{c}\text { Sum of } \\
\text { squared } \\
\text { value }\end{array}$ & Value & df & value & F & Significance \\
\hline Regress & 72.97 & 6 & 12.162 & 14.36 & 0.000 \\
Residual & 343.838 & 500 & 0.847 & & \\
Total & 416.809 & 506 & & & \\
\hline
\end{tabular}

As can be seen from Table 4, the F value is 14.36 , and the results are significant at a confidence level of 0.05 .

Table 5. Test results of coefficient of model

\begin{tabular}{cccc}
\hline Variable & Beta & T value & Significance \\
\hline$\beta 0$ & 3.753 & 82.879 & 0.000 \\
F1 & 0.16 & 3.534 & 0.000 \\
F2 & 0.21 & 4.629 & 0.000 \\
F3 & 0.113 & 2.498 & 0.000 \\
F4 & 0.205 & 4.532 & 0.001 \\
F5 & 0.189 & 4.158 & 0.005 \\
F6 & 0.13 & 2.859 & 0.004 \\
\hline
\end{tabular}


Table 5expresses that in the linear model of overall satisfaction and common factors, the probability ( $\mathrm{p}$ value) of each common factor coefficient $\mathrm{t}$ test tends to 0 , and the significance level $\alpha$ is 0.05 . Since each $p$ value is significantly less than 0.05 , the null hypothesis should be rejected and the factor parameters are not zero. The model is:

$$
\mathrm{Y}=3.753+0.16 \mathrm{~F}_{1}+0.21 \mathrm{~F}_{2}+0.113 \mathrm{~F}_{3}+0.205 \mathrm{~F}_{4}+0.189 \mathrm{~F}_{5}+0.13 \mathrm{~F}_{6}
$$

$\mathrm{Y}$ is the overall satisfaction, $\mathrm{F}_{1}$ is "Embodiment of historical elements". When other common factors are unchanged, if $F_{1}$ changes 1 unit, the overall satisfaction will change 0.16 units.

Similarly, the variations by 1 unit of $F_{2}$ ("The blend of tradition and modernity"), $F_{3}$ ("Industry distribution and type"), $\mathrm{F}_{4}$ ("Consumer demand"), $\mathrm{F}_{5}$ ("Street layout and function"), and $\mathrm{F}_{6}$ ("Landscaping") will cause the variation of overall satisfaction by 0.21 units, 0.113 units, 0.205 units, 0.189 units and 0.13 units respectively.

In summary, when it comes to the influence of the common factors, the sequence decreasingly is "The blend of tradition and modernity" "Consumer demand" " Street layout and function"、"Embodiment of historical elements"、"Landscaping" and "Industry distribution and type".

\subsection{Analysis of common factors' weight and satisfaction}

According to above results, the common factors' weight and satisfaction are taken as the ordinate for the importance-performance analysis matrix analysis. In the scatter plot of common factor weight and satisfaction (Figure 4), it can be seen that all factors are in the 1, 2, and 4 quadrants.

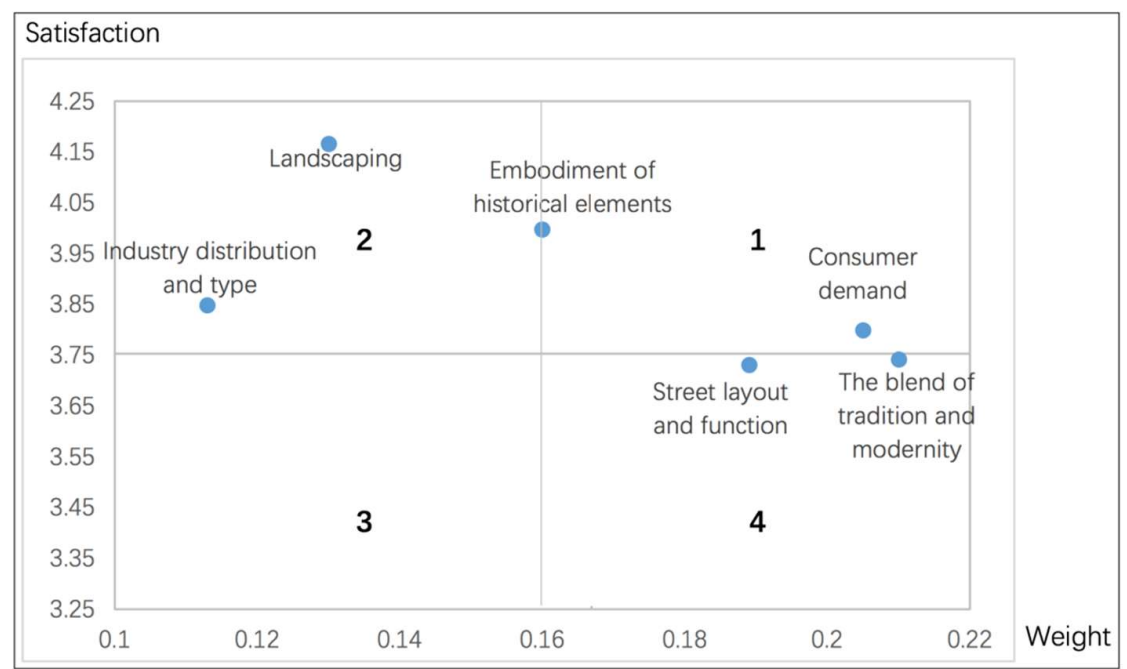

Figure 4. The scatter plot of common factors' weight and satisfaction 
The three most influential factors for comprehensive evaluation are "The blend of tradition and modernity", "Consumer demand", "Street layout and function". These three common factors are distributed in two quadrants: strong importance, high satisfaction(Quadrant 1) and strong importance, low satisfaction(Quadrant 4). Attention should be paid to the consumption needs of tourists, the integration of traditional elements of the district and modern culture, special activities, street management, and relationship among stakeholders.

Coexistence image of tradition and modern, activation of ancient architecture and inheritance of traditional culture show a strong influence on the symbiosis of traditional culture and modern culture from the perspective of cultural inheritance. Cultural inheritance is the primary condition for the development of historical districts. It achieves new development on the basis of inheriting the cultural charm of traditional cities and meeting consumer demands, which enhances the vitality of historical districts. Therefore, in the future development of historical districts, traditional urban culture should be integrated with modern needs to promote the formation of modern urban cultural character.

The demands for leisure experience and spiritual relief are the basic conditions for the survival and development of historical districts. The realization of the cultural experience function of historical districts through the "experience" and "leisure" modes is an important factor to obtain tourists' support. The historical district mainly creates a consumption space with romantic atmosphere, culture and art, and increases the leisure culture symbol of the historical district in line with modern consumption demand.

In the layout of the district, the node space and the dynamic line layout can be utilized to ensure the satisfaction of the diversified leisure experience in the tourist area to create a humanized and characteristic historical district.

"Embodiment of historical elements", "Industry distribution and type" and "Landscaping" are in the quadrant of weak correlation and high satisfaction (Quadrant 2), indicating that the historical and cultural characteristics of the district are significant, while the landscape quality and tourism resources are unique. However, in these relatively common places, it can be seen that under the existing beautiful environment and historical characteristics, tourists pay more attention to the overall environment and consumer demand, address the realization of leisure and entertainment functions. Therefore, the landscape quality and historical and cultural parts can maintain the status quo, and focuses should be on the parts that need improvement urgently. 


\section{Discussion and conclusions}

(1) Based on six dimensions: "Embodiment of historical elements", "The blend of tradition and modernity", "Industry distribution and type", "Consumer demand", "Street layout and function" and "Landscaping", this study from the perspective of tourists explores the influencing factors of tourism development model of historical districts. While three elements of "The blend of tradition and modernity", "Consumer demand" and "Street layout and function" have a great influence, "Embodiment of historical elements", "Industry" Distribution and type" and "Landscaping" have less impact.

(2) This study cuts through the perspective of tourists and finds that if historical districts achieve the goal of effective protection, sustainable development, and excellent living environment, they need to consider six dimensions, which mainly include historical culture, consumer demand and streets management. The mechanism between the dimensions is the key to ensuring the development of historical districts and the satisfaction of tourists (Figure 5).By focusing on the protection and management of stakeholders' demands and changes, the cooperation between public and private interests should be balanced to promote the sustainable development of the district.

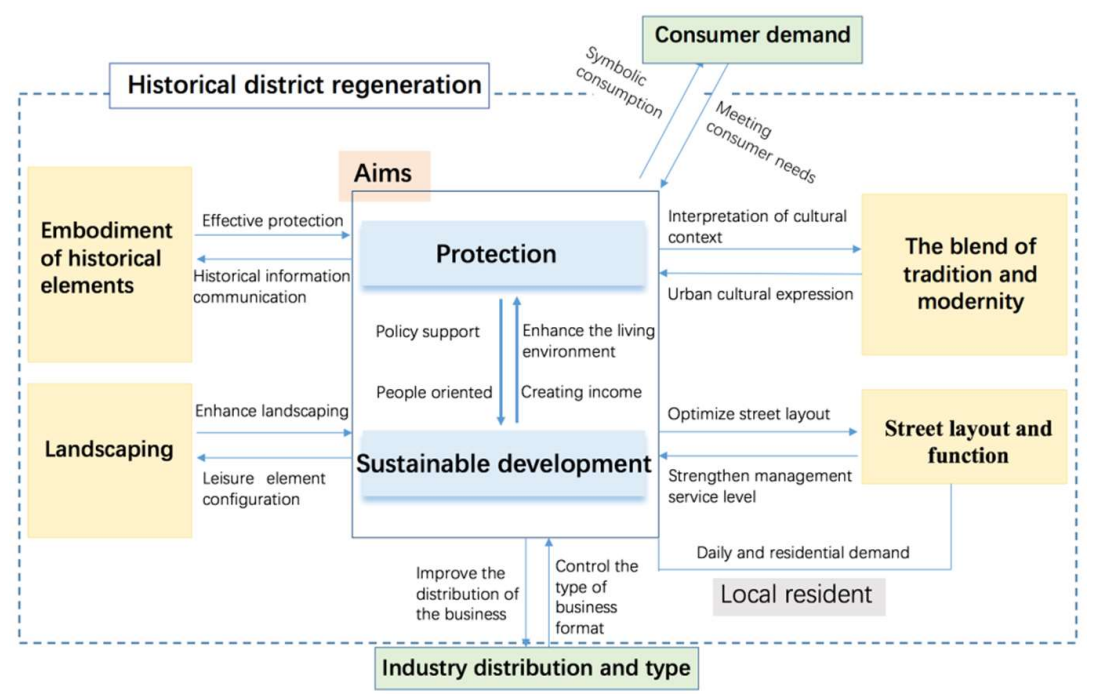

Figure 5. Sustainable development mechanism of historical districts with the integration of urban culture and consumer demand

First of all, the connotation of historical districts is its cultural characteristics. Even under the background of globalization, historical culture and regionality cannot be replaced. The regeneration of historical districts is an important effort to integrate local historical characteristics with the life of modern people. On the basis of protecting historical culture, the integration of traditional history and modern needs can help the development of historical districts. During the development process, it is important to protect its historical context and promote the symbolism of the district. 
Secondly, it benefits to improve the satisfaction and support of tourists by satisfying the leisure experience of tourists and the variety of business types. Adding the cultural experience function in the business configuration can obtain the support of tourists and establish the leisure culture symbols of the district, thus forming a unique consumption space and achieving the purpose of the benign development of the district.

Finally, the distract layout and the landscape space have an impact on the support of tourists. The landscape space creates a unique spatial image by displaying the characteristic landscape of the historical district, which promotes the formation of a historical street image with distinctive styles, and improves the satisfaction and support of tourists. At the same time, reasonable street layout should pay attention to the planning of residential and commercial facilities, avoiding the interference between the action space of the tourists and aboriginal living space. By coordinating the spatial layout, a comfortable, convenient and charming district environment can be established.

\section{References}

1. Steven, H. Anchoring. Princeton Architectural Press.1991.

2. Christian, N.S. Genius Loci: Towards a Phenomenology of Architecture. New York: Rizzoli. 1980.

3. Zhang, X.Y; Chen, T. Influence mechanism of tourism development on intangible cultural heritages (ICH) based on the perception of tourists: A case study of traditional handicraft Suzhou Embroidery. Geographical Research. 2016, 35(3), 590 604.

4. Liu, J.M.; Tao, W.; Guo, Y.Z. Discussion on the tourism development of traditional dwelling houses: A case study of pingyao ancient city. Geography Research. 2000, 19(3), 264 270.

5. Xiao, J.; Guo, K. Review, Key Issues, and Methodology of Historic District Preservation Studies. Urban Planning Forum. 2017, 3, 110-118.

6. Lu, J.W.; Wang, Y. The Making of Distinctive Vibrant District: A Strategy of Urban Regeneration. Urban Planning Forum. 2016, 6,101-108.

7. Yang, Z. Urban Design and Urban Regeneration: The British Experience as a Reference to China. Urban Planning Forum. 2016, 1, 88-98.

8. Lin, L. Conservation of Historic and Cultural Cities in the Context of the New Normal: Perspective of Historic Urban Area. Urban Planning Forum. 2016, 4, 94-101.

9. Yu, Y.; Gao, H.B., Wang, G. "Micro Centers" Revitalized the Historic District: Study on the Renewal of the Suzhou Xuanqiaoxiang Historical District Against the Background of "Smart City".

Urban Development Studies. 2017, 24(10),35-40. 
10. Deng, W.; He, Y., Hu, H.Y. Exploration on Integrated Conservation of Historic City in the New Period: The Case of Ningbo. Urban Planning Forum. 2016, 4, 87-97.

11. Liao, Y.L.; Fang, Z.; Qu, X.Q. Thought on spirit construction in traditional block. Sichuan Building Science. 2010, 36(6), 221 224.

12. Tao, H.; Liu, J.M. Principles and practices of local hard landscape designing in geopark: A case of mark monument designing in Wensugeopark, Xinjiang. Geographical Research. 2014, 33(9), $1758 \sim 1767$.

13. Bian, L.C.; Jing, Z.J. Some Thoughts on Conservation Planning of Historic Area: A case study of conservation planning of historic site in Shichahai. City Planning Review. 2005, 9, 44 59.

14. Shao, Y.; Hu, L.J.; Zhao, J.; Chen, H. A Research on the Conservation Plan of the HumanHabitat World Heritage: Case Study of Pingyao Ancient City. Urban Planning Forum. 2016, 5, $94 \sim 102$.

15. Liang, J.; Zhang, R.R. City Characteristic Block and Planning Strategies: Based on Wuhu City. Urban Planning Forum. 2016, 6:92-100.

16. Zhang, C.J. A Research of Shanghai Li-long Spaces from a Heritage Perspective. Urban Planning Forum. 2015, 4, 111-118.

17. McIntosh A. Into the tourist's mind: understanding the value of the heritage experience. Journal of Travel \& Tourism Marketing, 1999, 8(1), 41-64.

18. Yang, J.M. The culture catalytic study of urban regeneration. Tongji university, 2008.

19. Zhou, Q.Y.; Liu, Z.X.; Zhu, C.et al. Regional Economics. China Renmin University Press. 1999.

20. Yin, X.R. Study on Evaluation Index System and Model Building for Old Industrial Dist rict. Southeast University, 2009.

21. Yang, L.X.; Yu, X.C. A Summary of Chinas researches on the protection and utilization of cultural heritage. Tourism Tribune.. 2004, 19(4),85-91.

22. Zhang, P.Y. Urban regeneration: Theory and Practice in China's new urbanization. Urban Planning. 2004,4,25-30.

23. $\mathrm{Xu}, \mathrm{H}$.; Fan, Q. A Study on the Obstacles and Competitiveness Promotion Strategy of Chinese Tourism Industrial Convergence. Tourism Science, 2008,22(4), 1-5.

24. Doo, L.J. A Study on the Elements of Urban Image in Korean Traditional Residential Area: The Case of Bukchon Korean Traditional Residential Area. Master Dissertation of Chungang University.

2003.

25. Lee, D.H. Bukchon Hanok Village visitors of motivation, tourism image, awareness of the perceived value comparison: Koreans and the Activities of foreigners. Master Dissertation of 
Hanyang university. 2016.

26. Hwuang, I.W. The Old Town Regeneration Project and Space Conflicts: A Case Study of Jeonju Hanok Village Development Project. Doctoral Dissertation of Chonbuk National University. 2015.

27. Seo, J.W.; Liu, L.; Wu, H. Chinese Tourism Research Related to the Subject of South Korea: A Content Analysis. Progress in Geography.2009, 28(11), 153-160.

28. Jung, J.H. A Study on the Conservation of District Characteristics through the Special Zone Districts in Insadong District. Doctoral Dissertation of University of Seoul. 2010.

29. Seo, I.Y. A Study on the policy of Insadong Cultural District: Focused on the Place Marketing Strategies of City Government. Master Dissertation of University of Seoul. 2006.

30. Kang, E.J. A Study on Post Occupancy Evaluation of historic streets' improvement projects:

The case study of Jung-dong road and Insadong road in Seoul. Master Dissertation of University of Seoul. 2013.

31. Kim, S.Y. Importance-Performance Evaluation of Street scape on Insadong Road. Master Dissertation of Hanyang University. 2010.

32. Zhang, X.Y.; Chen. T. Influence mechanism of tourism development on intangible cultural heritages (ICH) based on the perception of tourists: A case study of traditional handicraft Suzhou Embroidery. Geographical Research. 2016, 35(3), 590-604.

33. Zhong, S.E.; Zhang, J.H.; Ding, L. Multi-dimension Influential Factors of Tourist Satisfaction in the Ancient Waterfront Towns in the South of the Changjiang River. Scientia Geographica Sinica. 2016, 36(11), 1715-1721.

34. Zhang, H.X.; Zhou, L.Q. Factor Components and Differences of the Park-based Recreational Happiness for Urban Residents: A Case Study of Hangzhou. Scientia Geographica Sinica. 2013, 33(9), 1074-1081.

35. Lu, S.; Wu, X. Assessment of tourist satisfaction of the painting tourism in the ancient villages: The case study of Hongcun village, Yixian county. Geographical Research. 2017, 36(8), 1570-1582.

36. Yu, W.Y.; Feng, Y.F.; Liang, J.M. Hakka Culture Tourism Development based on Tourist Satisfaction. Scientia Geographica Sinica. 2013, 33(7), 824-830 